Arch. Tierz., Dummerstorf 51 (2008) 6, 611-619

Department of Animal Science, Faculty of Agriculture, Canakkale Onsekiz Mart University, Canakkale, Turkey

MEHMET MENDES

\title{
Asymmetry measures and allometric growth parameter estimates for investigate effect of early feed restriction on deviation from bilateral symmetry in broiler chickens
}

\begin{abstract}
The purpose of this study is to investigate the effect of different feeding programs such as ad libitum feeding (AD), $20 \%$ feed restriction based on ad libitum group (FR1) and not fed between 9 a.m. and 3 p.m. (FR2) on deviation from bilateral symmetry or developmental stability in broiler chickens by means of two different approaches namely asymmetry measures and allometric growth model parameters. The weekly left and right sides of shank length, shank width, wing length and face width of chickens were collected from 7 days of age to 42 days of age. Results of this study showed that the deviations from the bilateral symmetry were mostly in fluctuating asymmetry (FA) in the FR1 group birds. On the other hand, the deviations from the bilateral symmetry in the birds in group AD and FR2 were mostly in the form of anti-symmetry (AS) and directional asymmetry (DA) respectively. In this study, the deviation from the bilateral symmetry was mostly in FA type for the measured morphological characters for the FR1 group, and the FA level was usually lower indicating higher welfare level and lower developmental instability for these animals than that of the AD and FR2 groups. Allometric growth coefficients for evaluating the effects of the feeding programs on the developmental stability were a little bit different from the findings obtained by the asymmetry measures ' being taken into account. Allometric growth parameters, therefore, should be taken into consideration, along with asymmetry measures when investigating effect of rearing conditions or environmental conditions on developmental stability. As a conclusion, intensive feeding (AD) and long-term feed restriction (FR2) can be said as an important environmental factor affecting developmental stability and dependently the animal welfare and performance.
\end{abstract}

Keywords: bilateral symmetry, allometric growth function, developmental stability, repeated measurement, broiler chickens

\section{Zusammenfassung}

Titel der Arbeit: Asymmetriemessungen und Schätzung allometrischer Wachstumsparameter zur Untersuchung des Einflusses früher Futterrestriktionen auf Abweichungen der Bilateralsymmetrie bei Broilern Es wurden bei Broilern der Einfluss unterschiedlicher Fütterungsprogramme wie Ad-libitum-Fütterung (AD), $20 \%$ Futterrestriktion bezogen auf die Ad-libitum-Gruppe (FR1) und einer Langzeitrestriktionsgruppe (FR2) auf die Abweichung von der Körpersymmetrie und Entwicklungsstabilität bei ausgewählten Körpermaßen mittels allometrischer Wachstumsfunktionen untersucht. Erfasst wurden links und rechtsseitig die Unterschenkellänge, -breite, Flügellänge und die Stirnbreite am 7. und 42. Lebenstag. Die größten Abweichungen von der Bilateralsymmetrie (BS) zeigten sich als wechselnde Asymmetrie (FA) in der FR1-Gruppe. Auf der anderen Seite fanden sich diese Abweichungen von der BS in den Gruppen DA und FR2 in Form von Antisymmetrie bzw. gerichteter Asymmetrie. Die Abweichungen von der BS bei Tieren mit FA bezogen sich auf die morphologischen Merkmale der FR1-Gruppe. Die FA war normalerweise gegenüber den AD- und FR2Tieren niedriger und verbunden mit besserer Gesundheit und geringerer Entwicklungsinstabilität. Die Schätzungen der allometrischen Wachstumskoeffizienten zur Auswirkung der Fütterungsvarianten auf die Entwicklungsstabilität unterschieden sich geringfügig von den asymmetrischen Messungen. Im Zusammenhang mit asymmetrischen Messungen sollte daher der Effekt der Zucht- oder Umweltkondition bei der Bewertung der Entwicklungsstabilität in Betracht gezogen werden. Zusammenfassend wird festgestellt, dass sowohl eine intensive Fütterung (AD) als auch eine Langzeitfutterrestriktion (FR2) als wichtige Umweltfaktoren auf die Entwicklungsstabilität wirken und Wohlbefinden und Leistungen davon abhängen.

Schlüsselwörter: beiderseitige Symmetrie, allometrische Wachstumsfunktion, Entwicklungsstabilität, Wieder holungsmessungen, Broiler 


\section{Introduction}

Today fast growing broiler chickens have a large appetite and high body weight gain in a short time. This large appetite and some other negative raising and environmental conditions together may cause some problems such as low meat quality, acides, flipover syndrome, left-right sides differences of bilateral traits and some other health problems (SHAHIN and EL AZEEM, 2005; SHAHIN and EL AZEEM, 2006; MENDEŞ et al., 2007). One of the ways used to prevent these problems is the feed restriction programs applied in the early periods (PETER et al., 1997; BEYNI and HABI, 1998; GONZALES et al., 1998; SAVORY and LARIVIERE, 2000; TUMOVA et al., 2002). However, although feed restriction programs applied are effective in taking control of the fast development to some extent, they cause stress on the animals. As a result of this, some undesirable, negative situations are likely to be seen. A decline yield and feed efficiency and important derivations from the bilateral symmetry may happen. It's an undeniable fact that the performances of the symmetric animals are higher than those which are not symmetric (MANNING and OCKENDEN, 1994). This shows how important it is to investigate the effects of the raising conditions applied on the deviation from the bilateral symmetry.

As is known, the right and left sides of any morphological character are expected to grow at equal levels or display a similar growth in symmetric animals. But in practice, the situations where the right and left sides of the animals are not grown at equal levels or don't display a similar growth are seen often. This is a situation shaped depending on genetical structures, rearing and the other environmental conditions of the animals in question (CLARKE et al., 1986; YALÇIN et al., 2003; CAMPO et al., 2005). Environmental stress may affect developmental stability, thus, increasing variation among individuals. In poultry, developmental instability mostly derive from the fact that more birds are kept in each $\mathrm{m} 2$ (stocking density), appropriate lighting program is not applied, feeding programs carried out (ad libitum and feed restriction) and some other negative conditions in the poultry house (MOLLER et al., 1995; YANG et al., 1997; AL-MAHROUS, 1997; MOLLER et al., 1999; YALÇIN et al., 2003).

Developmental stability cannot be measured directly. Some asymmetrical measures such as directional asymmetry (DA), fluctuating asymmetry (FA), anti-symmetry (AS) and relative asymmetry (RA) are commonly used in the determination of the developmental instability with respect to the characters in question (CAMPO et al., 2005). MOLLER et al (1995) reported that FA levels may be used to represent animal welfare status. But trying to determine if the animals have animal developmental instability or asymmetry by making use of only these measures is not enough. Because these measures only take into consideration the shape of the distribution showed by the difference between the left and the right differences of bilateral traits and the mean and variance of the distribution in question. This situation can give reliable results especially when worked with large samples. But when it is taken into consideration that mostly small samples are used in practice, it is not enough to try to determine if the animals have developmental instability or not with respect to the character or characters in question by making use of only these four measures. On the other hand, even when large samples are concerned, in each period a different asymmetry measurement can be observed. Or, with regard to the properties which dealt with, the shape of the distribution may not normal as well as the mean difference of right-left 
may be significantly different from zero. In such situations as well, making evaluation for developmental stability by using only asymmetry measurements, is not sufficient. Besides this, some other measures are needed. When this is considered, apart from the measures in question, it is quite beneficial that what kind of growth is displayed by the animals with respect to the right and left sides of the character in question is clearly stated. In other words, it is beneficial that the parameter estimates about the allometric growth model are given together with the asymmetry measures in question. Because, by making use of the allometric growth parameters, it is possible to show what kind of a growth is displayed by the right and left organs of the animals in comparison with each other. In this study, the effects of the different feeding programs, evaluated together with the asymmetry measures and allometric growth coefficient, to the developmental stability of the broilers are investigated.

\section{Materials and Methods}

Data of this study came from 60 broiler female chickens. Chickens were divided into three groups as: ad libitum (AD) group, the group with the $20 \%$ feed restriction based on $\mathrm{AD}$ group (FR1) and the group that was not feed between 9 a.m. and 3 p.m. (FR2). There were 20 female chicks in each group. Feed restriction programs were applied to the birds between 7 days of age to 21 days of age. Starting from 22 days, all the groups were switched to ad libitum feeding until day 43. Nipple drinker and round feeder were used to satisfy of water and feed requirement of birds. Water and feed was provided ad libitum with $23 \mathrm{~h}$ light and $1 \mathrm{~h}$ dark throughout the trial. Birds were fed with starter diet between 0-3 weeks and with growth diet between 4-5 weeks and with finisher diet in the last week of the trial. The starter, growth and finisher diets of the birds included $24.09 \%$ crude protein, $2,818 \mathrm{kcal} / \mathrm{ME}$ and $25.32 \%$ crude protein, 2,892 $\mathrm{kcal} / \mathrm{ME}, 22.38 \%$ crude protein, $2912 \mathrm{kcal} / \mathrm{ME}$ respectively under intensive condition. The weekly body weights (BW, g), left and right shank length (SHL, mm), shank width (SHW, mm), wing length (WL, mm) and face width (FW, mm) of the same birds were measured at same ages from 7 days of age to 42 days of age. SHL, SHW, WL and FW were measured using a digital caliper.

\section{Asymmetry Measures}

Directional asymmetry (DA), fluctuating asymmetry (FA), anti-symmetry (AS) and relative asymmetry (RA) were used as measures for deviation from bilateral symmetry. DA was defined as mean not zero with normal distribution. Therefore, DA is an asymmetry in which growth on a given side consistently exceeds that on the other side. AS was defined as mean zero with non-normal distribution and FA was defined as mean zero with normal distribution based on absolute differences between left and right sides $(|\mathrm{L}-\mathrm{R}|)$. FA is one of the measures of developmental instability of quantitative properties resulting from errors in developmental processes, though it might also include undetected environmental effects (VAN VALEN, 1962; KAWAHARA, 1974). Therefore, the FA can be defined as the asymmetry due to chance fluctuation in the development of the left and right sides of body or organs. RA was defined as the ratio of the absolute value of left-right differences divided to by the value for the size of the trait. Therefore RA was computed as:

$$
R A=(|L-R| /[\{L+R\} / 2]) \cdot 100
$$

(VAN VALEN, 1962; PALMER, 1996; YANG and SIEGEL, 1998; YALÇIN et al., 2003). 


\section{Statistical Analyses}

Shapiro-Wilk and paired t-tests were used to test for normality distribution with a mean of zero (WINER et al., 1991; MENDEŞ and PALA, 2003). YANG et al. (1999), and YALÇIN et al. (2001) informed that relative asymmetry (RA) can be a valid measure of genetic stressors, rearing and environmental conditions. Especially, with regard to morphological characteristics taken into consideration, by using the relative asymmetry (RA) measurement, comparing the effect of the types of feeding programs applied when more than one asymmetry measurements occur simultaneously on the developmental stability or bilateral symmetry, can give more reliable results. By this motivation, in investigation of the effect of the tree feeding program on the bilateral deviation, the RA measurement is used as well. The effect of feeding programs, ages (weeks) and interaction between them on relative asymmetry (RA) and body weight (BW) were tested by repeated measurement analysis of variance (ZAR, 1999). Statistical analyses were performed by NCSS and Minitab statistical package programs.

\section{Allometric Growth}

In this study, a simple allometric function was also used to describe the relation between the left of the body (Y) against the right of body (X). The allometric growth equation described as follow:

$$
Y=a X^{b} \text { or } \log Y=\log a+b \log X
$$

where $Y=$ the value of left side of the morphological character, $X=$ the value of right side of the morphological character, $a=$ the allometric constant or intercept, $b=$ the allometric growth coefficient or slope. The coefficient $b$ is defined as the allometric coefficient. If $b>$ than 1 , then $Y$ is growing at a faster rate than $X$, and vice versa (allometric growth). If $b=1$ then growth of both sides are similar or the same (isometric growth).

\section{Results}

The effect of the feeding programs on developmental stability changes with respect to the ages or weeks (Table 1). In general, with regarding to four morphological character measures on birds in $\mathrm{AD}$ group, the deviations from bilateral symmetry occurring as AS, attract attention. As the deviations from bilateral symmetry with regard to the shank length, the shank width and the wing length of birds in FR1 group, occurs as FA, for face width it occurs as AS. But for the birds in FR2 group, it can be observed that, the deviations from bilateral symmetry with regard to shank length occurs as AS, with regard to shank width it occurs as DA. On the other hand, how the deviations from bilateral symmetry with regard to wing length and face width would occur, couldn't have been observed. Because with regard to those two morphological characteristics, the shape of the distribution of the difference of right-left didn't display normally distributed as well as the mean of the difference of right-left is significantly different from zero. However, in order to determine how the deviations from bilateral symmetry occur using the measurements such as AS, FA and DA which used as asymmetry measurements, the three requirements below must be satisfied.

For $\mathrm{FA} \Rightarrow|L-R| \operatorname{Normal}\left(\mu=0 ; \sigma^{2}\right)$

For $\mathrm{DA} \Rightarrow \mid L-R \cong \operatorname{Normal}\left(\mu \neq 0 ; \sigma^{2}\right)$

For $\mathrm{AS} \Rightarrow|L-R| \cong \operatorname{Nonnormal}\left(\mu=0 ; \sigma^{2}\right)$ 
Table 1

Types of asymmetry by groups and weeks (Asymmetrietypen nach Gruppen und Wochen)

\begin{tabular}{llclllllllllc}
\hline \multirow{2}{*}{ Week } & \multicolumn{3}{c}{ Shank length } & \multicolumn{3}{c}{ Shank width } & \multicolumn{3}{c}{ Wing length } & \multicolumn{3}{c}{ Face width } \\
& AD & FR1 & FR2 & AD & FR1 & FR2 & AD & FR1 & FR2 & AD & FR1 & FR2 \\
\hline 1 & AS & FA & FA & AS & FA & DA & FA & FA & FA & AS & DA & $?$ \\
2 & AS & FA & FA & FA & FA & AS & AS & FA & FA & DA & FA & $?$ \\
3 & FA & FA & AS & FA & FA & FA & AS & FA & FA & FA & AS & FA \\
4 & FA & AS & FA & AS & FA & DA & AS & FA & FA & AS & AS & $?$ \\
5 & FA & FA & FA & DA & AS & DA & FA & FA & $?$ & AS & $?$ & $?$ \\
6 & AS & FA & AS & FA & FA & FA & FA & FA & FA & AS & AS & $?$ \\
overall & AS & FA & AS & AS & FA & DA & AS & FA & $?$ & AS & AS & $?$ \\
RA & b & b & a & b & b & a & c & b & a & bc & b & a \\
\hline
\end{tabular}

$\mathrm{AS}=$ anti-symmetry $; \mathrm{FA}=$ flactuating asymmetry, $\mathrm{DA}=$ directional asymmetry; $?=$ not determined

Results of repeated measurement for relative asymmetry (RA) and body weight $(B W)$ increments

There were statistically no significant differences for the calculated RA values of the shank length among the groups $(\mathrm{P}=0.7901)$, weeks $(\mathrm{P}=0.1055)$ and groups by age interaction $(\mathrm{P}=0.2618)$. The calculated $\mathrm{RA}$ values for shank width were statistically significant for weeks $(\mathrm{P}=0.0001)$ but not significant for the groups $(\mathrm{P}=0.9928)$ and groups by weeks interactions $(\mathrm{P}=0.2661)$. It has seen that the differences in the RA values calculated for the wing length and face width of birds in $\mathrm{AD}$ and treatment groups (FR1 and FR2) changing by the weeks (group $\times$ week interaction effect; $\mathrm{P}=0.001$ ). Therefore, the effect of the feeding programs on relative asymmetry has displayed disparateness with respect to the week of the birds. After Bonferroni multiple comparison test, it has been observed that the difference between the groups began to be obvious, beginning from second week for the wing length and face width. But the effect of the feeding programs on relative asymmetry began to be observed from the beginning of the first week of the trial.

The overall relative asymmetry (RA) values for shank length, shank width and face width was significantly larger in FR2 group birds than that in the AD and FR1 group birds (in the last row of Table $1 ; \mathrm{P}<0.05$ ). The RA for these traits were found to be similar for $\mathrm{AD}$ and FR1 groups $(\mathrm{P}>0.05)$. On the other hand, the RA value for wing length was significantly larger in FR2 group than that of the FR1 and AD groups $(\mathrm{P}<0.05)$.

Table 2

Results of repeated measurements analysis of variance for body weight increment (Varianzanalyse der Wiederholungsmessungen für den Gewichtszuwachs)

\begin{tabular}{lcc}
\hline Source of variation & P-Value & Observed Power \\
\hline week & 0.000 & 1.000 \\
group & 0.000 & 0.903 \\
week $\times$ group & 0.000 & 0.856 \\
\hline
\end{tabular}

It has seen that the effect of the groups on body weight increment has changed with respect to the week of the birds (Table 2; group $\mathrm{x}$ week interaction effect; $\mathrm{P}=0.000$ ). After Bonferroni multiple comparison test, it has been observed that the difference between the groups began to be obvious, beginning from second week.

\section{Results Allometric growth curves}

Simple monophasic allometric function was used for the description of differential growth of left and right sides of the morpohological characters and results are present in Table 3. 
Table 3

Parameter estimates based on Allometric growth curves

(Schätzungen der Körpermaßparameter basierend auf allometrischen Wachstumskurven)

\begin{tabular}{|c|c|c|c|}
\hline & $\mathrm{AD}$ & FR1 & FR2 \\
\hline Shank length & $\mathrm{L}=1.089 \cdot \mathrm{R}^{0.988}$ & $\mathrm{~L}=1.080 \cdot \mathrm{R}^{0.992}$ & $\mathrm{~L}=1.132 \cdot \mathrm{R}^{0.994}$ \\
\hline Shank width & ${ }^{* *} \mathrm{~L}=0.972 \cdot \mathrm{R}^{0.864}$ & ${ }^{* *} \mathrm{~L}=0.984 \cdot \mathrm{R}^{0.948}$ & ${ }^{* *} \mathrm{~L}=0.937 \cdot \mathrm{R}^{1.389}$ \\
\hline Wing length & $\mathrm{L}=1.045 \cdot \mathrm{R}^{1.012}$ & $\mathrm{~L}=0.982 \cdot \mathrm{R}^{1.003}$ & ${ }^{*} \mathrm{~L}=0.955 \cdot \mathrm{R}^{1.047}$ \\
\hline Face width & ${ }^{* *} \mathrm{~L}=1.371 \cdot \mathrm{R}^{1.343}$ & $\mathrm{~L}=1.195 \cdot \mathrm{R}^{0.995}$ & ${ }^{*} \mathrm{~L}=0.942 \cdot \mathrm{R}^{0.956}$ \\
\hline
\end{tabular}

$*=\mathrm{P}<0.05 ; * *=\mathrm{P}<0.01$

As Table 3 is examined, the growth is observed to be isometric with regard to the left and right shank length $(\mathrm{b}=0.988 ; \mathrm{P}>0.05)$ and wing length $(\mathrm{b}=1.012 ; \mathrm{P}>0.05)$ of the birds in $\mathrm{AD}$ group. In other words, the right and left shank length of the birds in this group display a similar growth. The same situation is valid for wing length as well. Therefore, the deviations observed from bilateral symmetry with regard to these two characters, are ignorable. On the other hand, the growth of shank width $(b=0.864$; $\mathrm{P}<0.01)$ and face width $(\mathrm{b}=1.343 ; \mathrm{P}<0.01)$ for the birds in this group is observed to be allometrical. The left shank width of the birds in this group, has displayed slower growth wit respect to those of right. Notice that, it can be seen that, the growth of the morphological characteristics which can be expressed as length in birds in AD group occurs isometrical, for all that the growth of the characteristics which can be expressed as width occurs allometrical. The birds in FR1 group generally displayed a similar structure to those in $\mathrm{AD}$ group. It is seen that the birds in this group have a developmental instability with respect to the shank width $(b=0.948 ; \mathrm{P}=0.000)$. Except the shank, the growth of the other characteristics of the birds in FR1 group can be observed as isometric. The left shank width of the birds in this group displayed slower growth with respect to those of right.

It is seen that the shank width $(\mathrm{b}=1.389 ; \mathrm{P}=0.000)$, wing length $(\mathrm{b}=1.047 ; \mathrm{P}=0.042)$ and face width $(\mathrm{b}=0.956 ; \mathrm{P}=0.038)$ of the birds in group FR2 (the group which was not given food for 6 hours) had deviations from the bilateral symmetry at significant levels. Except the shank width, the growth of the other characteristics of the birds in FR2 group can be observed as allometric. The growth occurs faster in left side with regard to the shank width and wing length with respect to those of right, the growth of the right part with regard to face width occurred faster, with respect to the left.

\section{Discussion}

Results of this study showed that the deviations from the bilateral symmetry in the FR1 group birds are realized as FA except face width. This is an indication that the deviations from the perfect symmetry in birds in FR1 group are at negligible levels. PALMER and STROBECK (1992) informed that fluctuating asymmetry (FA) was the most suggested measure or index of developmental instability. Since very low level of fluctuating asymmetry (FA) is an indication of small deviation of the most of the birds in the group from perfect symmetry or lack of asymmetry in the birds (MOLLER and MANNING, 2003). Likewise, MOLLER et al. (1995) reported that levels of FA may be accepted as a measurement of animal welfare status. On the other hand, the deviations from the bilateral symmetry in the birds in group AD are mostly in the form of AS except shank length. The deviations from the bilateral symmetry in the birds in group FR2 are mostly in the form of DA. This situation indicates that the animals in group FR2 show significant deviations from the perfect symmetry. The fact that the deviations 
from the symmetry are mostly in the form of DA also show that the growth at one side of the morphological character is lower or higher in comparison with the other side As deviations from bilateral symmetry increased, some abnormalities of developmental stability may appearance in animals (MOLLER and POMİANKOWSKİ, 1993; MOLLER and SWADDLE, 1997; MOLLER et al., 1999; MOLLER and MANNING, 2003). This may cause in negative changes in the performances of animals and thereby economic losses. The animals with low FA are expected to have higher performance. MANNING and OCKENDEN (1994) showed, in race horses, a good level of symmetry between front leg and head is associated with a higher performance. As known, the most important performance measure in quails is body weight. In the birds possessing a low level of deviation from bilateral symmetry, developmental instability is rare, and the body weight in slaughter age is expected to be high. Thus, the birds in the AD and FR1 groups averaged a higher slaughter weight as compared to those in the FR2 group $(2,124.20 \mathrm{~g}$ and $1,997.67 \mathrm{~g}$ vs. $1,621.30 \mathrm{~g} ; \mathrm{P}=0.034)$. Feed conservation ratios for AD (1.82) and FR1 (1.72) groups were higher than that of the FR2 (2.14) group as well. These results suggest that the significance changes in FA level can affect developmental stability and in turn feed conservation ratio and slaughter weight significantly.

It is seen that the findings which make use of the coefficient of the allometric growth while evaluating the effects of the feeding programs in question to the developmental stability are a little bit different from the findings obtained by the asymmetry measures' being taken into account. This is an expected situation. Because depending on the fact that whether the mean of the distribution of DA, FA and AS, which are among the asymmetry measures in question, is zero or not, and whether the distribution is normal or not, you get the information to determine if there is a developmental instability or not. But in practice, when it is taken into consideration that fewer animals are used, it is not possible to get adequate information about the effects of the raising conditions applied to the developmental stability just by using the mean and shape of the distribution. Apart from these, some other measures should be considered. Using this information, the growth of the morphological character in question at the right and the left sides of the body is compared. The growth of one part of body in comparison with the other part or the whole body is called allometric growth. And while commenting on the results of growth, the parameter $b$, which is the allometric growth coefficient, is used. In this research, allometric growth coefficients are used when investigating the growth of the left side of the morphological character in comparison with the right side of the morphological character. In this research, it is seen that the animals in AD group have a similar growth considering left and right sides of shank length and wing length. On the other hand, the birds in this group have not similar growth considering left and right sides of shank width and face width. Therefore, feeding of animals as ad libitum, didn't form significant deviations from bilateral symmetry for the shank length and wing length. On the other hand, it formed significant deviations from bilateral symmetry for the shank width and face width. But the direction of the deviations from bilateral symmetry for those of two morphological characteristics was different. Therefore it can be concluded that ad libitum feeding programs have an important role in possible deviations from bilateral symmetry for shank width and face width, however, the direction of the deviations chances with respect to the characteristic taken into consideration. It has been observed that, the $20 \%$ feeding restriction (FR1) applied in early (7-21 days) period of 
time, did't form important deviations from bilateral symmetry for the other characteristics except the face width. It is seen that the right side has grown more in comparison with the left side with respect to shank width.

It is seen that the shank width, wing length and face width of the birds in group FR2 (the group which was not given food for 6 hours) had deviations from the bilateral symmetry at significant levels. The growth at the left sides of the birds in this group with respect to the shank width and wing length has been higher to great extent when compared with their right sides. On the other hand, it is seen that the right side has grown more in comparison with the left side with respect to face width.

In this study, the deviation from the bilateral symmetry was mostly in FA type for the measured morphological characters for the FR1 group, and the FA level was usually lower indicating higher welfare level and lower developmental instability for these animals than that of the AD and FR2 groups. As a conclusion, intensive feeding (AD) and long-term feed restriction (FR2) can be said as an important environmental factor affecting developmental stability and dependently the animal welfare and performance. On the other hand, it should be bear in mind that by only one observed asymmetrical character, only more general predictions can be done. Since, the developmental instability is dependent to many factors (GANGESTAD and THORNHILL, 1999). Thus, allometric growth parameters should be taken into consideration, along with asymmetry measures when investigating effect of rearing conditions or environmental conditions on developmental stability.

\section{AL-MAHROUS, M.:}

\section{References}

Einfluss des Alters von Broilern bei Beginn eines Nachtlichtprogrammes auf die Mastleistung. Arch. Tierz. 40 (1997), 159-164

BEYNI, K.; HABI, H.:

Effects of food restriction during the finishing period on the performance of broiler chickens. Br. Poult. Sci. 39 (1998), 423-425

CAMPO, J.L.; GIL, M.G.; DAVILA, S.G.;MUNOZ, I.:

Estimation of heritability for fluctuating asymmetry in chickens by restricted maximum likelihood. Effects of age and sex. Poult. Sci. 84 (2005), 1689-1697

CLARKE, G.M.; BRAND, G.W.; WHITTEN, M.J.:

Fluctuating asymmetry: a technique for measuring developmental stress caused by inbreeding. Aust. J. Biol. Sci. 39 (1986), 145-153

GANGESTAD, S.W.; THORNHILL, R.: Individual differences in developmental precision and fluctuating asymmetry: a model and its implications. J. Evol. Biol. 12 (1999), 402-416

GONZALES, E.; JUNQUEIRA, O.M.; MACARI, M.; ANDREATTI-FILHO, R.L.; GARCIA, E.A.: Using quantitative feed restriction to decrease mortality of male broilers. Rev. Brasil. Zootecn. 27 (1998), 129-136

KAWAHARA, T.: Bilateral asymmetry in the transverse processes of the cervical vertebrae in the chicken. Japan J. Gen. 49 (1974), 1-9

MANNING, J.T.; OCKENDEN, L.: Fluctuating asymmetry in male sexual ornaments may reliably reveal male quailty. Anim. Behav. 40 (1994), 1185-1187

MENDEŞ, M.; PALA, A.:

Type I error rate and power of three normality tests. Pakistan J.Inf. Techn. 2 (2003), 135-139

MENDEŞ, M.; DINÇER, E.; ARSLAN, E.:

Profile analysis and growth curve for body mass index of broiler chickens reared under different feed restrictions in early age. Arch. Tierz. 50 (2007), 403-411

MOLLER, A.P.; POMIANKOWSKI, A.:

Punctuated equilibria or gradual evolution: The importance of fluctuating asymmetry. J. Theor. Biol. 161 (1993), 359-367 
MOLLER, A.P.; SWADDLE, J.P.:

Asymmetry, Developmental Stability and Evolution. Oxford (1997)

MOLLER, A.P.; MANNING, J.:

Growth and developmental instability. Vet. J. 166 (2003), 19-27

MOLLER, A.P.; SANOTRA, G.S.; VESTERGAARD, K.S.:

Developmental stability in relation to population density and breed of chickens Gallus gallus. Poult. Sci. 74 (1995), 1761-1771

MOLLER, A.P.; SANOTRA, G.S.; VESTERGAARD, K.S.:

Developmental stability and light regime in chickens Gallus gallus. App. Anim. Behav. Sci. 62 (1999), 57-71

PALMER, A.R.; STROBECK, C.:

Fluctuating asymmetry as a measure of developmental stability: implications of non-normal distributions and power of statistical tests. Acta Zool. Fennica 191 (1992), 57-72

PETER, W.; DANICKE, S.; JEROCH, H.:

Einfluss der Ernahrungsintensitat auf den Wachstumsverlauf und die Mastleistung französischer „LABEL“ Broiler. Arch. Tierz. 40 (1997), 69-84

SAVORY, C.J.; LARIVİERE, J.M.:

Effects of qualitative and quantitative food restriction treatments on feding motivational state and general activity level of growing broiler breeders. App. Anim. Behav. 69 (2000), 135-147

SHAHIN, K.A.; EL AZEEM, F.A.:

Effect of breed, sex and diet and their interactions on carcass composition and tissue weight distribution of broiler chickens. Arch. Tierz. 48 (2005), 612-626

SHAHIN, K.A.; EL AZEEM, F.A.:

Effect of breed, sex and diet and their interactions on fat deposition and partitioning among depots of broiler chickens. Arch. Tierz. 49 (2006), 181-193

TUMOVA, E.; SKRIVAN, M.; SKRIVANOVA, V.; KACEROVSKA, I.:

Effect of early feed restriction on growth in broiler chickens, turkeys and rabbits. Czech J. Anim. Sci. 47 (2002), 418-428

VAN VALEN, L.:

A study of fluctuating asymmetry. Evolution 16 (1962), 125-142

WINER, B.J.; BROWN, D.R.; MICHELS, K.M.: Statistical principles in experimental design. $3^{\text {rd }}$ Ed., McGraw-Hill, Inc., USA, (1991)

YALÇIN, S.; OZKAN, S.; TURKMUT, L.; SİEGEL, P.B.:

Responses to heat stress in commercial and local broiler stocks : II. Developmental stability of bilateral traits. Brit. Poul. Sci. 42 (2001), 153-160

YALÇIN, S.; ÖZKAN, S.; ÇABUK, M.; SIEGEL, P.B.:

Criteria for evaluating husbandry practices to alleviate heat stres in broilers. J. App. Poult. Res. 12 (2003), 382-388

YANG, A.; SIEGEL, P.B.:

Asymmetry and heterosis of bileteral traits in parental lines of chickens and their F1 crosses. J. Anim. Genet. 115 (1998), 105-111

YANG, A.; DUNNINGTON, E.A.; SIEGEL, P.B.:

Developmental stability in stocks of White Leghorn chickens. Poult. Sci. 76 (1997), 1632-1636

YANG, A.; EMMERSON, D.A.; DUNNINGTON, E.A.; SİEGEL, P.B.:

Heterosis and development of body and organ weights at hatch for parental line broiler breeders and speci.c crosses among them. Poult. Sci. 78 (1999), 941-948

ZAR, J.H.:

Biostatistical analysis. New Jersey (1999)

Author:

Assoc. Prof. Dr. MEHMET MENDES

Animal Science Department; Agriculture Faculty

Canakkale Onsekiz Mart University

17020 Çanakkale

Turkey

email: mmendes@comu.edu.tr 